\title{
Fresh cow mastitis monitoring on day 3 postpartum and its relationship to subsequent milk production
}

\author{
K. L. Anderson, ${ }^{* 1}$ M. T. Correa, ${ }^{\star}$ A. Allen, ${ }^{\star}$ and R. R. Rodriguez ${ }^{\star} \dagger$ \\ *Department of Population Health and Pathobiology, College of Veterinary Medicine, North Carolina State University, Raleigh 27606 \\ †Advanced Animal Diagnostics Inc., Durham, NC 27713
}

\begin{abstract}
The purpose was to determine the association of milk California Mastitis Test (CMT), somatic cell concentration (SCC), and milk differential cell count results on day 3 postcalving with subsequent lactation production and health events. On d 3 postcalving, the CMT was performed and quarter milk samples were collected from 130 dairy cows. Quarter SCC and milk differential cell counts were determined. Microbiology on duplicate quarter milk samples was used to determine the presence of intramammary infection by major or minor pathogens. Production measures obtained using Dairy Herd Improvement Association testing were 150-d standardized and summit milks. Milk culture results on a cow basis included $82(63.1 \%)$ samples with no growth, $31(23.9 \%)$ with major pathogens, and $17(13.1 \%)$ with minor pathogens. Milk culture results comparing cows with no growth to those with any growth (major or minor pathogens) were not associated with statistically significant differences in milk production. Milk culture results comparing cows with major pathogens to those with no growth and minor pathogens combined were associated with statistically significant differences in 150 d milk. Milk production did not differ for cows with CMT results above and below a cut-off of trace, and for SCC results above and below cut-offs of 200,000, 300,000 , and $400,000 / \mathrm{mL}$, respectively. Statistically significant differences in milk production were found for cows above and below cut-offs for percentage neutrophils in milk and for absolute neutrophil counts. Associations were found for milk production and number of quarters $(0,1,2$, or 3 and 4 combined) above respective cut-offs for SCC, percentage neutrophils in milk, and absolute numbers of neutrophils in milk, but not for CMT. Milk production differed for cows experiencing any health event versus those with no health event. The most commonly recorded health event was clinical mastitis. Statistically significant associations were detected
\end{abstract}

\footnotetext{
Received November 6, 2009.

Accepted July 19, 2010.

${ }^{1}$ Corresponding author: kevin_anderson@ncsu.edu
}

between health events and milk culture results, SCC, neutrophil percentage, and neutrophil absolute counts. Results of the present investigation indicate that milk monitoring on d 3 of lactation using milk neutrophil percentage or neutrophil absolute counts may be useful as an indication of subsequent milk production.

Key words: fresh cow, mastitis monitoring, production

\section{INTRODUCTION}

Assessment of udder health is one component of fresh cow monitoring programs (Dingwell et al., 2003, 2004; Aalseth, 2005; Quaife, 2005; Pfizer Animal Health, 2009). This assessment is important because udder health in the periparturient period is a major determinant of subsequent milk production and quality (Harmon, 1994; Schukken et al., 2003; De Vliegher et al., 2004). Udder infections are common in early lactation, and economically significant levels of udder infections have been reported in fresh cows and heifers on most dairies (Britten, 2004). The economic benefits of detecting and eliminating quarter infections early in lactation may be substantial, including prevention of clinical mastitis, decreasing discarded milk, and reducing bulk milk tank SCC (Dingwell et al., 2003). Intervention opportunities include treatment, segregation, and culling (Britten, 2004).

Both on-farm efforts and research studies have considered the monitoring of udder health postpartum (Sargeant et al., 2001; Britten, 2004; Dingwell et al., 2004; Wallace et al., 2004; Rampino et al., 2006). The most common program is that of simple observation for clinical mastitis in fresh cows (Britten, 2004). Another approach is to use cost-effective and rapid screening tests to select animals for further assessment or action, such as individual milk culture, treatment, or both. The California Mastitis Test (CMT) and milk SCC have been investigated for use in udder health screening in fresh cows (Barkema et al., 1999; Sargeant et al., 2001; DeVliegher et al., 2004; Rampino et al., 2006). Utilization of differential cell counts on cow milk samples has recently been studied and may have promise in diag- 
nosis of mastitis (Pillai et al., 2001; Rivas et al., 2001; Anderson et al., 2006).

For practical purposes, the only reliable way to diagnose microbiological etiology of mastitis is to culture every quarter of cows as they calve in a herd. Because this is costly and time-consuming, it would be desirable to have an economical and reliable method to screen cows that are likely to be infected (Sargeant et al., 2001). Both the CMT and SCC have been evaluated for this use (Barkema et al., 1999; Sargeant et al., 2001; Schukken et al., 2003; Britten, 2004; DeVliegher et al., 2004; Rampino et al., 2006). Utilization of SCC for early-lactation udder health monitoring has been investigated (Sargeant et al., 2001; DeVliegher et al., 2004; Rampino et al., 2006). On-farm use of SCC from DHI testing for fresh cow monitoring may be limited, however, because test dates are unlikely to allow testing of all cows in early lactation (Dingwell et al., 2003; Britten, 2004).

The CMT has been described as a rapid, accurate, and economical test that can be used on fresh cows (Dingwell et al., 2003). Sargeant et al. (2001) studied associations between the SCC and CMT with IMI in 131 cows from 3 herds during the first $10 \mathrm{~d}$ postpartum. They found the greatest sensitivity and specificity for the CMT for samples taken on d 3 after calving using a threshold reaction of greater than zero (Sargeant et al., 2001). The CMT has been regarded as a "powerful management technique" for fresh cows, and it has been suggested that it can reliably be used on fresh cow colostrum (Britten, 2004). Britten (2004) recommended that individual quarters scoring 3 on a CMT are cause for concern with regard to mastitis and milk quality.

Utilization of differential cell counts may have value in fresh cow monitoring. The percentage of neutrophils in a milk sample, derived from a differential cell count, is highly correlated with the overall SCC (Pillai et al., 2001). Culture-positive milk samples have been shown to contain a higher percentage of neutrophils than culture-negative samples (Pillai et al., 2001). However, it is uncertain whether differential cellular analysis of early postpartum milks may be more useful than the SCC or CMT as indicators of subsequent milk production.

Fresh cow monitoring is based on the principle that detection and correction of early lactation problems would be expected to maximize subsequent milk production. Detecting and managing early lactation IMI should have benefits in terms of subsequent production. Issues to address include when to monitor, what to monitor, and whether or not monitoring makes a difference in subsequent production or health. There is also the obvious question of what to do when a problem is detected.
The purpose of this study was to determine if selected measures of udder health, including milk differential cell counts, evaluated on d 3 postpartum were associated with subsequent milk production and health events. We hypothesized that the differential cell count, specifically the neutrophil measures, from milk from d 3 postcalving would be most relevant with respect to subsequent milk production compared with the SCC or CMT.

\section{MATERIALS AND METHODS}

\section{Study Design}

Quarter milk samples were evaluated and cultured from each heifer and cow calving from November 2006 to February 2007. In a previous study, Sargeant et al. (2001) evaluated the milk SCC and CMT in calving cows for the first $10 \mathrm{~d}$ postpartum and found that the CMT done on $\mathrm{d} 3$ postcalving with a threshold reaction of greater than zero was most sensitive and specific for detecting intramammary infections. Based on this report, we designed our study considering d 3 postpartum and addressed 2 questions: Were test results on d 3 postpartum associated with subsequent milk production and which of the measures evaluated were associated with subsequent milk production?

\section{Animals}

Milk samples and health records for 130 Holstein, Jersey, and Jersey $\times$ Holstein cows calving on a dairy from November 2006 to February 2007 were used in the study. The herd consisted of 165 total milking cows, with a rolling herd average of $6,600 \mathrm{~kg} / \mathrm{yr}$, an average milk production of $25 \mathrm{~kg} / \mathrm{d}$, and an average linear SCS of 2.7. Cows were fed a grain mix and minerals, had access to pasture, and were fed corn silage and grass baleage as needed. Cows were excluded from the study if any evidence was found of clinical mastitis, other disease, or antibiotic treatment from the period from 2 wk before calving to the day of milk collection at 3 d postpartum. Animal use was reviewed and approved by the North Carolina State University Institutional Animal Care and Use Committee.

\section{Sample Collection and Testing}

Quarter milk samples were tested by the CMT, and then teats were aseptically prepared as described herein. Duplicate quarter milk samples were collected in 13-mL vials for milk culture and determination of SCC.

California Mastitis Test. The CMT was performed on each quarter sample as described and scored as recommended, with scores of negative (0), trace 
(0.5), 1, 2, or 3 (Immucell California Mastitis Test, ImmuCell Corp., Portland, ME; www.immucell.com). Farm personnel were specifically trained by the investigators to conduct and read the CMT before the start of the study. Laminated instruction sheets and explanations of scores were made readily available to users of the CMT, and retraining was conducted at least twice during the period of the study.

SCC and Differential Cell Counts. Somatic cell counts of quarter milks were determined (DeLaval Cell Counter DCC, DeLaval, Tumba, Sweden; www.DeLaval.com) on refrigerated duplicate samples at less than $24 \mathrm{~h}$ after collection. Samples were brought to room temperature before testing. As described by Sargeant et al. (2001), samples with clots or those too thick for standard processing were reported as $9,999 \times 10^{3} / \mathrm{mL}$. Differential cell counts were performed on each quarter milk sample, as described previously (Anderson et al., 2006). Averages of duplicate SCC and milk differential cell counts were reported for each quarter milk sample.

Collection and Microbiological Analysis of Milk Samples. Duplicate quarter foremilk samples were collected after aseptic preparation of the teats as described (Hogan et al., 2005). One set of duplicates was collected by preparing the cow aseptically and then repeating the process for the collection of the duplicate. Milk samples were immediately transported to the laboratory and processed for microbiological analysis within $14 \mathrm{~d}$ of collection. Milk was frozen at $-20^{\circ} \mathrm{C}$ if not immediately processed.

Duplicate quarter milk samples $(0.1 \mathrm{~mL})$ were plated and identification of pathogens performed according to published methods (Hogan et al., 2005). Major pathogens included Staphylococcus aureus, coliform bacteria (e.g., Escherichia coli, Klebsiella spp.), Streptococcus spp., Enterococcus spp., Arcanobacterium pyogenes, Nocardia spp., Serratia spp., Pseudomonas spp., Prototheca spp., and Bacillus cereus. The following microorganisms were classified as minor pathogens: CNS, Corynebacterium spp., yeasts, and Bacillus spp. other than $B$. cereus. Quarters with major pathogens were classified as infected only when the same result was obtained from both duplicates at any concentration. Quarters with minor pathogens were classified as infected if both duplicates had 100 colonies/mL or more of the same minor pathogen. If a sample contained both major and minor pathogens, then it was classified as containing a major pathogen.

\section{Milk Production and Health}

Health data were collected and recorded by farm personnel, and cows were classified as follows with respect to current lactation: code $0=$ no health problems; codes 1, 2, 3 = first, second, and third mastitis, respectively; code $4=$ other mammary gland problem such as udder edema; code $5=$ other illness such as hoof disorder or gastrointestinal tract disease; code $6=$ leaving the herd for mastitis; and code 7 = leaving the herd for any other reason.

Production data were obtained from DHIA records after record analysis by Dairy Records Management Systems (Raleigh, NC). Milk production was assessed using standardized 150-d milk and summit milk.

Standardized 150-Day Milk. Standardized 150-d milk is defined as milk production per day at 150 DIM (DHIA, 2007). Use of standardized 150-d milk allows removal of variation in test-day milk production due to variation in stage of lactation and allows milk production on any given day to be compared with that on another test date (DHIA, 2007). Standardized 150-d milk is only computed for cows at $\leq 330$ DIM (DHIA, 2007). Age and breed are adjusted for and 150-d milk projects backward or forward to 150 DIM using 36 standard lactation curves based upon 6 seasons (DHIA, 2007). For this investigation, standardized 150-d milk was obtained from the DHIA production testing closest to 120 DIM.

Summit Milk. Summit milk is defined as average milk production from the 2 highest of the first 3 monthly DHIA tests in a lactation (DHIA, 2007). Summit milk is closely correlated to overall lactation production (DHIA, 2007).

\section{Data Analysis}

Cows were classified into 3 breed groups, Holsteins, Jersey, and Holstein-Jersey crosses. Because calculation of 150-d milk did not fully account for breed considerations, a further adjustment was made by determining the deviation of each individual cow's milk production from the median milk production for the breed group for that particular variable.

Multiple variables were evaluated for association with milk production, based upon investigator experience or the report of Sargeant et al. (2001). Milk culture, CMT, SCC, and health events were evaluated as they are commonly used monitoring measures; percentage neutrophils and total neutrophils were evaluated because the neutrophil is the primary cell in response to mastitis (Harmon, 1994; Anderson et al., 2006). Most variables were evaluated for association with milk production in 1 of 2 ways. In the first approach, all cows with no quarter above the cut-off for the variable were compared with cows with one or more quarters above the respective cut-off. The intent here was to evaluate whether milk production differed for the given variable 
at or above a given cut-off. In a second approach, cows were considered in 4 groups, based upon number of quarters above a cut-off, including $0,1,2$, and 3 or 4 quarters above the cut-off, respectively. Cows with 3 and 4 quarters above the cut-off were combined because numbers per individual group were small and because it made sense biologically. The purpose of the second approach was to evaluate whether an increasing number of quarters at or above a given cut-off was associated with a difference in milk production.

As an example, consider CMT $\geq 0.5$ :

For 2 categories, 2 groups would be compared: (1) cows with no quarter with $\mathrm{CMT} \geq 0.5$; and (2) cows with 1 or more $(1,2,3$, or 4$)$ quarters with $\mathrm{CMT} \geq 0.5$.

For 4 categories, 4 groups would be compared: (1) cows with no quarter with $\mathrm{CMT} \geq 0.5 ;(2)$ cows with 1 quarter with $\mathrm{CMT} \geq 0.5$; (3) cows with 2 quarters with $\mathrm{CMT} \geq 0.5$; and (4) cows with 3 or 4 quarters with $\mathrm{CMT} \geq 0.5$.

Two indices based upon utilization of more than one variable were also considered. Several indices were initially investigated to determine if various combinations of absolute values for SCC, neutrophils, lymphocytes, phagocytes (neutrophils and macrophages), or macrophages, as well as percentages of neutrophils, lymphocytes, phagocytes (neutrophils and macrophages), or macrophages would yield better performance than single thresholds. Selection of the indices was based upon ability to predict culture results. The selection of thresholds for analysis was done using a data analysis program (Data Desk 6.0 for Windows, Data Description Inc., Ithaca, NY; www.datadesk.com). This program allowed rapid visual analysis of data to seek patterns and gain insight into data without the need for special training in statistics. For example, as shown in Figure 1 , to find the best candidates for a dual threshold involving neutrophil percentage and total neutrophils, a plot with $\log _{10}$ of absolute neutrophils as a continuous variable on the $\mathrm{x}$-axis was plotted against neutrophil percentage as a continuous variable on the y-axis. Then, a bar chart (not shown) involving the 3 different culture results (no growth, major pathogen, and minor pathogen) was evaluated.

The different culture categories were then visually coded to identify them. Visual inspection shows that the lower left-hand box, bound by $\log _{10}$ of neutrophils $<5$ (100,000 neutrophils/mL) and $<65 \%$ neutrophils, is primarily made up of negative cultures and minor pathogens with very few major pathogens, whereas the upper right-hand box, bound by $\log _{10}$ of neutrophils $\geq 5$ $(100,000$ neutrophils / $\mathrm{mL})$ and $\geq 35 \%$ neutrophils, is primarily made up of major and minor pathogens and relatively few samples with no growth.
Two indices were evaluated. Index 1 was based upon total absolute neutrophils and \% neutrophils in sample: if $\geq 100,000$ neutrophils $/ \mathrm{mL}$ in sample, then the sample was positive if $\geq 35 \%$ neutrophils, and negative if $<35 \%$ neutrophils; or if the sample contained $<100,000$ neutrophils $/ \mathrm{mL}$, then the sample was positive if $\geq 65 \%$ neutrophils, and negative if $<65 \%$ neutrophils. Index 2 was as described above, but the sample was initially classified as positive if SCC $>1,000,000 / \mathrm{mL}$.

Both indices were analyzed in 2 ways: First, cows were separated into 2 categories, cows with no (0) quarters positive were compared with those cows with one or more quarters positive for the index. Second, cows were separated into 4 categories, with categories based upon having $0,1,2$, or 3 and 4 quarters positive, respectively.

\section{Statistical Analyses}

The associations between measured variables and 150-d milk and summit milk production were analyzed using ANOVA (SAS Institute, 2002-2003). Statistical significance was considered present at an $\alpha$ level of $\leq 0.05$. The associations between health events and variables other than milk production were evaluated using the chi square test $(\alpha$ value $\leq 0.05)$.

\section{RESULTS}

Results are presented for 130 lactating cattle with measurements taken on d 3 postpartum as described. From these, $39(30.0 \%)$ cows were in lactation 1 and $91(70.0 \%)$ were in lactation 2 or higher. Of the 130 cows, 52 were Holstein (40\%), 52 were Holstein-Jersey crosses (40\%), and 26 (20\%) were Jerseys. Milk culture results on 130 animals on a cow basis included 82 cows $(63.1 \%)$ with no growth in all quarters, 31 (23.9\%) cows with major pathogens in one or more quarters, and $17(13.1 \%)$ cows with minor pathogens in one or more quarters. Culture results by lactation are presented in Table 1. Among major pathogens, Staph. aureus was most common, followed by streptococci; CNS were the most common minor pathogens.

Descriptive statistics for milk production for all 130 animals are given as arithmetic mean values; however, production measures were analyzed as deviations from group medians. For 150-d standardized milk, the mean $\pm \mathrm{SD}$ was $23.9 \pm 7.4 \mathrm{~kg} / \mathrm{d}$, with a minimum to maximum of 0.5 to $44.1 \mathrm{~kg} / \mathrm{d}$. Average DIM was 148.3, with minimum to maximum of 71 to 177 . Mean \pm SD summit milk was $27.1 \pm 8.2 \mathrm{~kg} / \mathrm{d}$, with a minimum to maximum of 10.0 to $49.1 \mathrm{~kg} / \mathrm{d}$. 


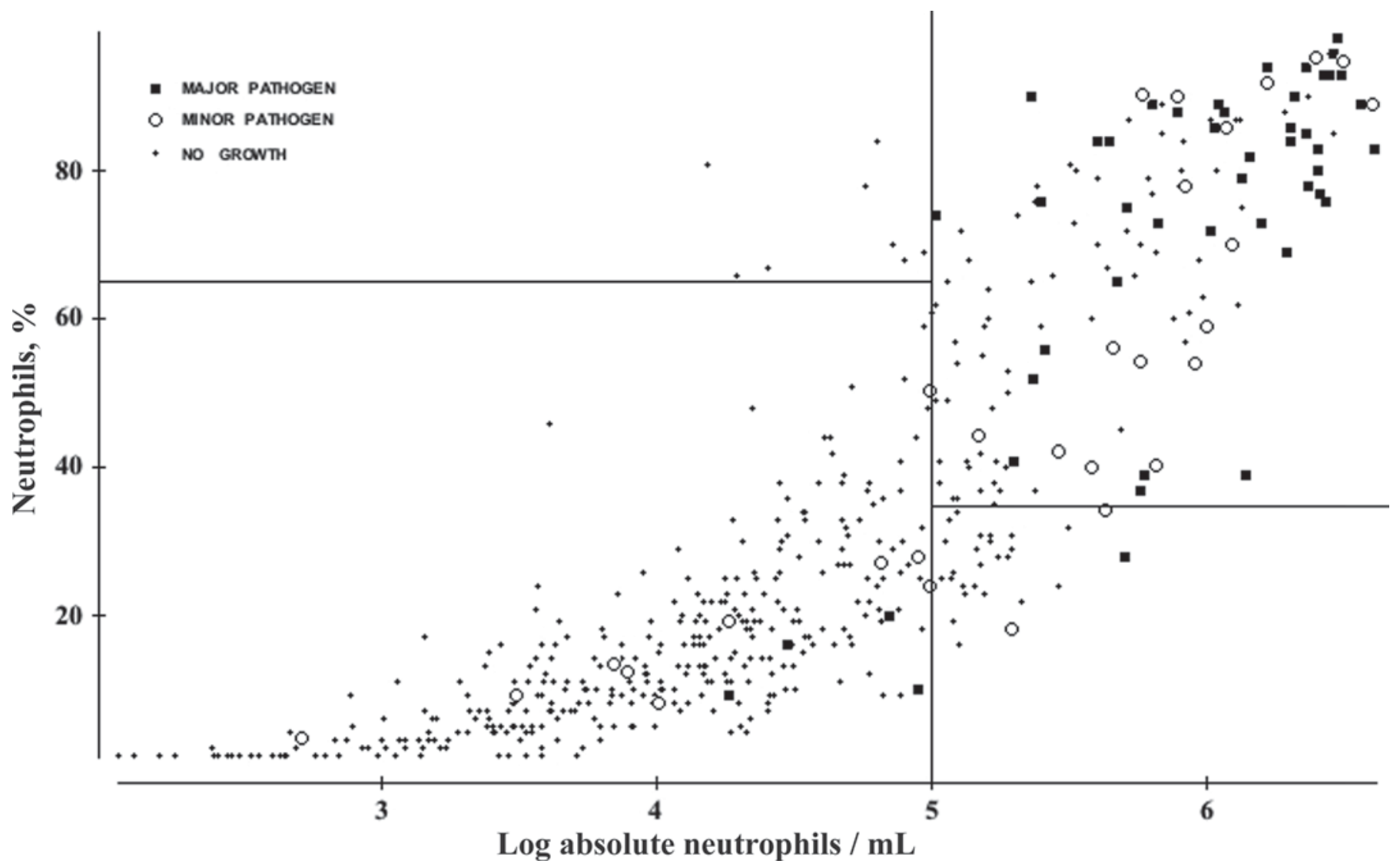

Figure 1. Study data illustrating index 1: milk neutrophil percentage versus $\log _{10}$ absolute neutrophils/mL for all quarters of 130 cows categorized by milk culture results of major pathogen, minor pathogen, or no growth. The vertical $\operatorname{line}_{\text {at }} \log _{10}$ of 5 separates samples at the $100,000 / \mathrm{mL}$ absolute neutrophil cut-off. The horizontal line in the lower right represents the cut-off at $35 \%$ neutrophils, and the upper left quadrant represents the cut-off at $65 \%$ neutrophils.

Health events included $86(66.2 \%)$ animals without a recorded health event. Twenty-one $(16.2 \%), 1(0.8 \%)$, and $3(2.3 \%)$ cows, respectively, had mastitis once, twice, or 3 times (codes 1,2 , and 3 ), respectively. Two $(1.5 \%), 8(6.2 \%), 5(3.8 \%)$, and $4(3.1 \%)$ cows had another udder problem (code 4), had any other illness (code 5), left the herd for mastitis (code 6), or left the herd for any other reason (code 7), respectively.

Results for ANOVA of the associations of lactation number, milk culture, and health events with milk production are presented in Table 2 (missing values allowed). Statistically significant differences were detected in milk production differences for first lactation versus lactation $\geq 2$ cows for 150 -d milks $(P=0.036)$ and for summit milks $(P<0.001)$. As shown in Table 3, mean differences \pm SEM for 150 -d and summit milks were $-1.65 \pm 0.96$, and $-7.24 \pm 0.83 \mathrm{~kg} / \mathrm{d}$, respectively, for first lactation versus $1.01 \pm 0.79$ and $2.66 \pm 0.64 \mathrm{~kg} / \mathrm{d}$ more for cows in lactations 2 and above. No statistically significant differences $(P>0.05)$ were found in milk production difference for 150 -d or summit milks for cows with all quarters producing no growth on milk culture compared with cows with any quarter producing any bacterial growth (minor or major pathogens). However, an association with milk production difference was found when cows with all quarters producing no growth or minor pathogens in one or more quarters were compared with cows with at least one quarter producing major pathogens (Table 2). For these groups, summit milks were not significantly different; however, mean difference for 150-d milk was significantly higher $(P=0.035)$ for cows with all quarters producing either no growth or minor pathogens $(\mathrm{n}=95$; mean \pm SEM; $0.95 \pm 0.72 \mathrm{~kg} / \mathrm{d}$ ) compared with those with major pathogens in at least one quarter $(\mathrm{n}=29$; mean \pm SEM; $-2.18 \pm 1.24 \mathrm{~kg} / \mathrm{d})$.

Health events in 2 or 3 categories were associated with significant differences in 150-d milk production $(P$ $=0.002$ and 0.004 , respectively; Table 2). For health events in 2 categories, 150-d milk difference for cows with no health event produced a mean milk difference $( \pm \mathrm{SEM})$ of $+1.54 \pm 0.75 \mathrm{~kg} / \mathrm{d}$ compared with a mean 
Table 1. Milk culture results from 130 cows tested at d 3 postpartum

\begin{tabular}{|c|c|c|c|c|c|c|c|c|c|c|}
\hline \multirow[b]{2}{*}{ Lactation } & \multicolumn{2}{|c|}{$\begin{array}{l}\text { Cows with no } \\
\text { pathogens }\end{array}$} & \multicolumn{4}{|c|}{ Cows with major pathogens } & \multicolumn{4}{|c|}{ Cows with minor pathogens } \\
\hline & Total & $\begin{array}{l}\% \text { of age } \\
\text { group }\end{array}$ & Total & $\begin{array}{l}\% \text { of age } \\
\text { group }\end{array}$ & $\begin{array}{l}\text { Cows, } \\
\mathrm{n}\end{array}$ & Organism $^{1}$ & Total & $\begin{array}{l}\% \text { of age } \\
\text { group }\end{array}$ & $\begin{array}{l}\text { Cows, } \\
\mathrm{n}\end{array}$ & Organism \\
\hline 1 & 28 & 71.8 & 9 & 23.1 & $\begin{array}{l}5 \\
1 \\
2 \\
1\end{array}$ & $\begin{array}{l}\text { Staphylococcus aureus } \\
\text { Staph. aureus }+ \text { Streptococcus dysgalactiae }+ \text { CNS } \\
\text { Staph. aureus }+ \text { Streptococcus uberis } \\
\text { Staph. aureus }+ \text { Arcanobacterium pyogenes }\end{array}$ & 2 & 5.1 & $\begin{array}{l}1 \\
1\end{array}$ & $\begin{array}{l}\text { CNS } \\
\text { Lactococcus lactis }\end{array}$ \\
\hline 2 & 25 & 71.4 & 5 & 14.3 & $\begin{array}{l}4 \\
1\end{array}$ & $\begin{array}{l}\text { Staph. aureus } \\
\text { Nocardia spp. }\end{array}$ & 5 & 14.3 & 5 & CNS \\
\hline 3 & 15 & 68.2 & 6 & 27.3 & $\begin{array}{l}1 \\
1 \\
1 \\
1 \\
1 \\
1\end{array}$ & $\begin{array}{l}\text { Nocardia spp. } \\
\text { Streptococcus bovis } \\
\text { Strep. uberis } \\
\text { Nocardia spp. + CNS } \\
\text { Enterococcus faecium + CNS } \\
\text { Strep. uberis + CNS }\end{array}$ & 1 & 4.5 & 1 & CNS \\
\hline 4 & 7 & 35.0 & 7 & 35.0 & $\begin{array}{l}2 \\
1 \\
1 \\
1 \\
1 \\
1\end{array}$ & $\begin{array}{l}\text { Staph. aureus } \\
\text { Strep. uberis } \\
\text { Klebsiella spp. } \\
\text { Strep. dysgalactiae + Staph. aureus } \\
\text { Strep. dysgalactiae + CNS } \\
\text { Strep. uberis / CNS + Strep. uberis }\end{array}$ & 6 & 30.0 & $\begin{array}{l}5 \\
1\end{array}$ & $\begin{array}{l}\text { CNS } \\
\text { Trichosporon spp. }\end{array}$ \\
\hline$\geq 5$ & 7 & 50.0 & 4 & 28.6 & $\begin{array}{l}1 \\
1 \\
1 \\
1\end{array}$ & $\begin{array}{l}\text { Enterococcus faecalis } \\
\text { Staph. aureus } \\
\text { Strep. uberis } \\
\text { Escherichia coli / Strep. uberis + CNS }\end{array}$ & 3 & 21.4 & 3 & CNS \\
\hline Total & 82 & & 31 & & & & 17 & & & \\
\hline
\end{tabular}

\footnotetext{
${ }^{1}+$ indicates organisms in different quarters; / indicates organisms in the same quarter.
} 
Table 2. Probability values from the ANOVA for milk production $(\mathrm{kg} / \mathrm{cow}$ per day) for lactation, milk culture, and health events

\begin{tabular}{lcc}
\hline & \multicolumn{2}{c}{$P$-value } \\
\cline { 2 - 3 } Variable & $\begin{array}{c}150-\mathrm{d} \\
\text { milk }\end{array}$ & $\begin{array}{c}\text { Summit } \\
\text { milk }\end{array}$ \\
\hline Lactation, first vs. second and greater & 0.036 & $<0.001$ \\
Culture, no growth vs. any growth & 0.065 & 0.239 \\
Culture, major pathogen vs. no growth and minor pathogens & 0.035 & 0.605 \\
Health events, 2 categories: no event vs. any event & 0.002 & 0.857 \\
Health events, 3 categories: none vs. mastitis vs. other & 0.004 & 0.699 \\
\hline
\end{tabular}

$( \pm$ SEM $)$ of $-2.65 \pm 1.02 \mathrm{~kg} / \mathrm{d}$ for cows with any health event (Table 3 ). For health events in 3 categories, cows with no health event produced a mean $( \pm$ SEM) of $+1.54 \pm 0.75 \mathrm{~kg} / \mathrm{d}$, cows with a mastitis event produced a mean $( \pm \mathrm{SEM})$ of $-1.67 \pm 1.32 \mathrm{~kg} / \mathrm{d}$, and those with any other health event produced a mean of -4.21 $\pm 1.59 \mathrm{~kg} / \mathrm{d}$ (Table 3 ). Health events considered in 2 categories (no event vs. any event) or 3 categories (no health event vs. mastitis vs. other health events) were not associated with significant differences in summit milks (Table 2).

Results of ANOVA for CMT, SCC, and differential cell count measures are given in Table 4 . The CMT, considered in 2 or 4 categories, was not associated with significant mean differences in production. For SCC, when considered in 2 categories (cows with no quarter at or above the threshold were compared with cows with one or more quarters at or above the threshold), no significant differences in milk production were found at SCC cut-offs of 200,000, 300,000, and 400,000/mL, respectively (not shown in Table 4). However, when SCC results were considered in 4 categories with respect to the number of quarters per cow above the cut-off $(0,1$, 2 , and 3 or 4 quarters, respectively), both the 200,000 / $\mathrm{mL}$ and $300,000 / \mathrm{mL}$ cut-offs were associated with sig- nificant differences $(P=0.044$ and 0.011 , respectively) in summit milks but not 150 -d milks (see Table 4). For SCC at a cut-off of $400,000 / \mathrm{mL}$ in 4 categories, both production measures showed significant differences $(P$ $=0.022$ and 0.001 , respectively) in production (Table 4).

For percentage neutrophil variables, neutrophil $30 \%$ in 2 categories was not associated with significant differences in production (Table 4). Neutrophil percentage cut-offs at $35 \%$ and $40 \%$ in 2 categories were associated with significant differences $(P=0.013$ for both $)$ in 150-d milk, but not in summit milk (see Table 4). No differences were found in production variables for neutrophil percentage cut-offs of both $35 \%$ and $40 \%$ in 4 categories (results not shown in table). However, a cut-off of $30 \%$ neutrophils in 4 categories was associated with significant differences in summit milks $(P=$ $0.020)$, but not in 150-d milks $(P=0.204)$.

Total absolute neutrophils at $150,000 / \mathrm{mL}, 200,000 /$ $\mathrm{mL}$, and $250,000 / \mathrm{mL}$ in 2 categories were all associated with significant differences $(P=0.003,0.004$, and 0.006 , respectively) in 150 -d milks, but not in summit milks (results not given in Table 4). However, as shown in Table 4, when considered in 4 categories (relative to the number of quarters per cow above the limit),

Table 3. Milk production differences (mean difference $\pm \mathrm{SEM}$; $\mathrm{kg} / \mathrm{cow}$ per day) for lactation, milk culture, and health events

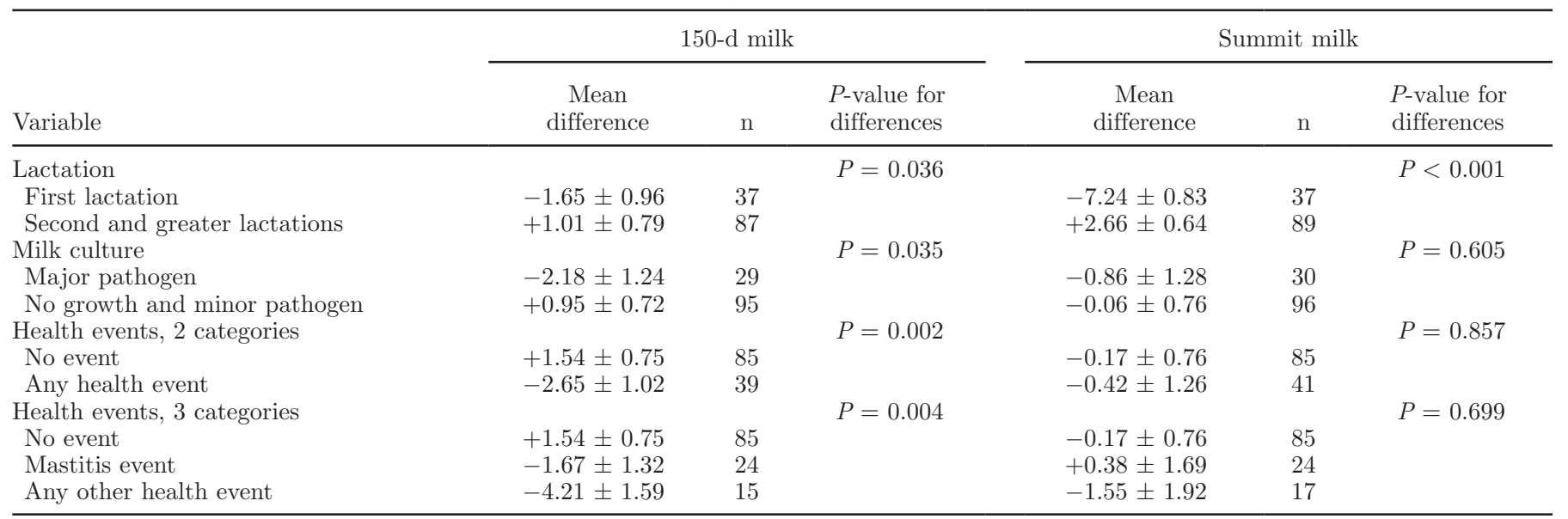


Table 4. Probability values from the ANOVA for milk production ( $\mathrm{kg} / \mathrm{cow}$ per day) for California Mastitis Test (CMT), SCC, and differential cell count measures

\begin{tabular}{lcc}
\hline & \multicolumn{2}{c}{$P$-value } \\
\cline { 2 - 3 } Variable & $\begin{array}{c}150 \text {-d } \\
\text { milk }\end{array}$ & $\begin{array}{c}\text { Summit } \\
\text { milk }\end{array}$ \\
\hline CMT, 2 categories & 0.932 & 0.537 \\
CMT, 4 categories & 0.417 & 0.350 \\
SCC $200,000 / \mathrm{mL}, 4$ categories & 0.240 & 0.044 \\
SCC $300,000 / \mathrm{mL}, 4$ categories & 0.105 & 0.011 \\
SCC $400,000 / \mathrm{mL}, 4$ categories & 0.022 & 0.001 \\
Neutrophil \%, 30, 2 categories & 0.070 & 0.394 \\
Neutrophil \%, 35, 2 categories & 0.013 & 0.147 \\
Neutrophil \%, 40, 2 categories & 0.013 & 0.226 \\
Total absolute neutrophils, $150,000 / \mathrm{mL}, 4$ categories & 0.022 & 0.028 \\
Total absolute neutrophils, $200,000 / \mathrm{mL}, 4$ categories & 0.025 & 0.016 \\
Total absolute neutrophils, $250,000 / \mathrm{mL}, 4$ categories & 0.031 & 0.022 \\
Index 1,2 categories & 0.002 & 0.091 \\
Index 2,2 categories & 0.002 & 0.103 \\
\hline
\end{tabular}

total absolute neutrophils at $150,000 / \mathrm{mL}, 200,000 / \mathrm{mL}$, and $250,000 / \mathrm{mL}$ were all associated with significant differences in $150-\mathrm{d}(P=0.022,0.025$, and 0.031 , respectively) and summit milks $(0.028,0.016$, and 0.022 , respectively). Both indices 1 and 2 were associated with significant differences in 150-d milks when considered in either 2 or 4 categories. For summit milk, no differences were found for 2 categories, but differences were found for 4 categories (results for 2 categories shown in Table 4).

Mean differences and corresponding standard errors of the mean $( \pm \mathrm{SEM})$ milk production for some comparisons are shown in Table 5. As expected, when considered in 4 categories, the largest mean differences were seen when 3 or 4 quarters were above the cut-off. As an example, mean (SEM) 150-d milks for SCC concentrations at a cut-off of $400,000 / \mathrm{mL}$ in 4 categories were $+1.45 \pm 0.87,-0.27 \pm 1.47,+0.40 \pm$ 1.04 , and $-5.86 \pm 1.91 \mathrm{~kg}$ for cows with $0,1,2$, and 3 or 4 quarters above the cut-off, respectively. For summit milk, means $( \pm \mathrm{SEM})$ were $+0.39 \pm 0.88,+1.06 \pm$ $1.11,+0.08 \pm 1.68$, and $-9.08 \pm 1.72 \mathrm{~kg}$, respectively, for cows with $0,1,2$, and 3 or 4 quarters above the cut-off. For neutrophil percentage in 2 categories at a cut-off of $40 \%$, mean ( \pm SEM) 150 -d milks were +1.80 $\pm 0.84 \mathrm{~kg} / \mathrm{d}$ with no quarter above the cut-off, and $-1.31 \pm 0.90 \mathrm{~kg} / \mathrm{d}$ for cows with one or more quarters above the cutoff. No significant differences in summit milks were found. For 150-d milks for total neutrophils in 4 categories at $150,000 / \mathrm{mL}$ cut-off, mean \pm SEM differences were $+2.06 \pm 0.84,-1.28 \pm 1.39,-0.66$ \pm 1.96 , and $-2.90 \pm 1.34 \mathrm{~kg} / \mathrm{d}$, respectively, for cows with $0,1,2$, and 3 or 4 quarters above the $150,000 /$ $\mathrm{mL}$ cut-off. For summit milks for total neutrophils in 4 quarters at $150,000 / \mathrm{mL}$ cut-off, mean \pm SEM differences were $+0.47 \pm 0.84,+0.41 \pm 0.97,+1.40 \pm 2.45$, and $-4.82 \pm 2.18 \mathrm{~kg}$, respectively, for cows with 0,1 , 2 , and 3 or 4 quarters above the $150,000 / \mathrm{mL}$ cut-off. Mean difference \pm SEM for 150 -d milk for index 1 for cows with no quarter above the limit of $+2.16 \pm 0.86$ was significantly different $(P=0.002)$ compared with $-1.66 \pm 0.87 \mathrm{~kg} / \mathrm{d}$ for cows with one or more quarters above the limit. No significant difference $(P=0.091)$ was found in summit milks for the 2 groups $(+0.87$ $\pm 0.82 \mathrm{~kg} / \mathrm{d}, \mathrm{n}=62$ ) with no quarter above the limit compared with that $(-1.33 \pm 0.99 \mathrm{~kg} / \mathrm{d}, \mathrm{n}=64)$ with one or more quarters above the limit.

Among associations between tested variables and milk production, occurrence of a health event was an important factor influencing milk production. The associations between these variables and health events (in 2 categories), but not milk production, were tested in a separate analysis using the chi square test. Results from the chi-square test indicated that CMT results (2 categories) were not significantly associated with health events. Milk culture results in 2 categories and SCC in 2 categories at all cut-offs were all significantly $(P<0.001)$ associated with health events. Differential cell count measures (neutrophil percentage at 3 cut-offs and absolute neutrophil counts at 3 cut-offs), as well as the 2 indices, were all significantly associated $(P \leq$ 0.001) with health events.

\section{DISCUSSION}

Results of the present study showed associations between variables representing a variety of udder health monitoring measures determined on d 3 postpartum and subsequent milk production. The CMT has been used most commonly in postpartum udder health monitoring and the SCC is the most readily available test. However, in this study, neither the CMT in 2 or 4 
Table 5. Milk production differences (mean difference $\pm \mathrm{SEM} ; \mathrm{kg} / \mathrm{cow}$ per day) for variables with differences in milk production

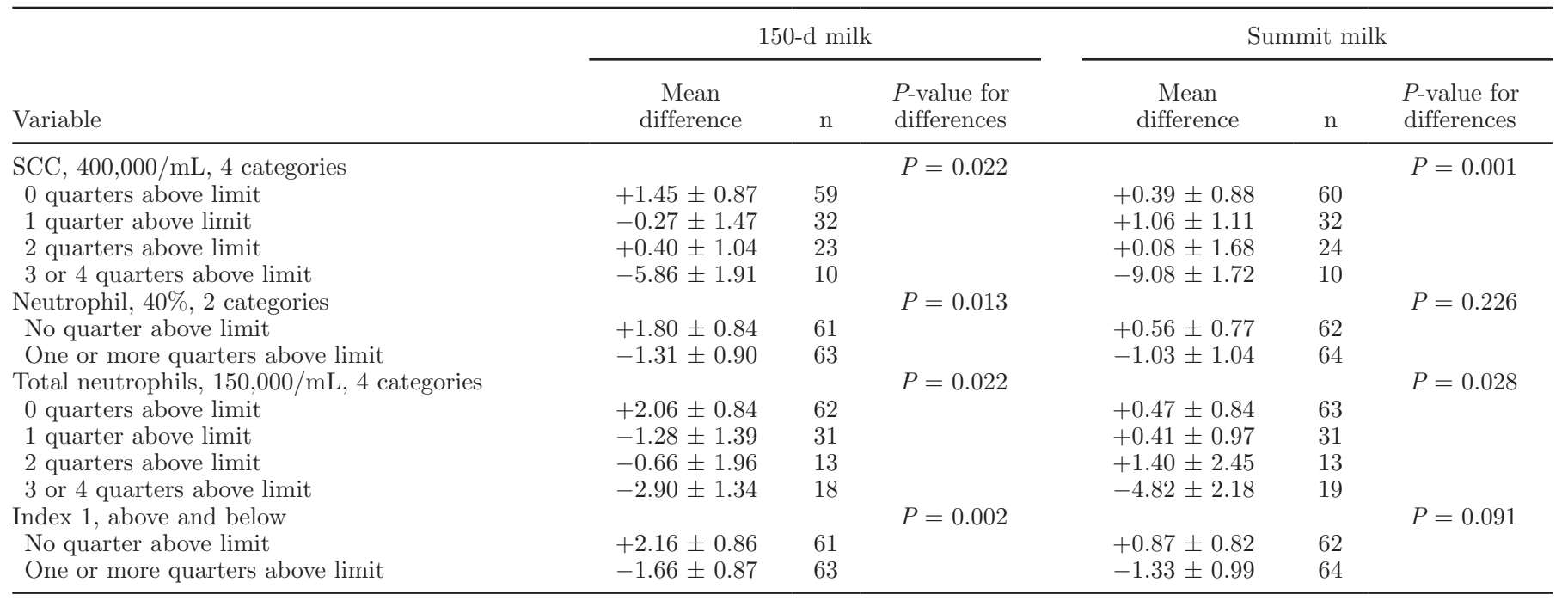

categories nor the SCC results when classified in 2 categories (above or below a cut-off value) were indicative of subsequent milk production. Only when the SCC was considered in 4 categories relative to the number of quarters above the cut-off were results of the SCC significantly associated with milk production. Both neutrophil percentage and total absolute neutrophils were associated with statistically significant differences in milk production. Although significant differences were found in this study, these results must be interpreted in the context that the study involved one herd and with consideration of the time involved from d 3 postpartum until determination of milk production. A limitation of the study is that it focused only on $\mathrm{d} 3$ postpartum. Day 3 was chosen based upon the results of Sargeant et al. (2001), who studied the association of the CMT and IMI on several days postpartum and found the greatest sensitivity and specificity for the CMT for samples on d 3 .

This study focused on milk production, which is an obvious and important consideration. The present emphasis on milk quality and payment of quality premiums provide the rationale for consideration of factors besides milk production, including SCC.

Fresh cow monitoring has been advocated for and used by many producers and veterinarians. The intent is to assess cow health and ensure that cows start the lactation healthy. Frequent monitoring and aggressive management of fresh cow disorders is important. Fresh cow monitoring has focused on metabolic diseases and reproductive tract conditions; however, udder health is also an important component. A limited number of studies have considered approaches to monitoring udder health in fresh cows. Important questions to be considered are when to monitor, what to monitor, and whether or not the monitoring makes a difference in subsequent production and health. There is also the question of how to manage the cow when a problem is detected.

Although production measures were not evaluated, a prior study (Barkema et al., 1999) clearly established the relationship between SCC and infection in early lactation. When considering fresh cows, a physiological increase in SCC was reported in foremilk for a period of 5 to $35 \mathrm{~d}$ after calving (Barkema et al., 1999). Barkema et al. (1999) demonstrated that geometric mean quarter milk SCC during the first 6 milkings after calving were different among quarters infected with major pathogens, those infected with minor pathogens, and those that were uninfected. Barkema et al. (1999) concluded that diagnostic use of the SCC on milk collected after the second day (milking 4 and later) after calving is feasible.

We chose to evaluate monitoring on d 3 postpartum, because Sargeant et al. (2001) found the greatest sensitivity and specificity of the CMT for detecting IMI to be that done on d 3. Day 3 also coincides with transition from colostrum to milk and is the time when many dry cow milk antibiotic residues are likely to be cleared. Moreover, CMT use on d 3 complies with the instructions of the manufacturer for use of the test in fresh cows. It is stated that testing should not be performed on colostrum, milk from fresh cows $(<3 \mathrm{~d}$ postcalving), or samples after dry-off (ImmuCell Corporation, www.immucell.com/). The CMT has been advocated for monitoring cows after calving. One US-based animal health company recommends using the CMT for screening of fresh cows for mastitis, with positive cows 
identified for treatment. In its fresh cow monitoring program, the company states that the CMT can be used on the first or second day after calving or as long as cows are milked into a bucket. The intent is to identify new infections as soon as possible. The recommendation is to treat new infections based on detection of a CMT 2 or 3 using approved intramammary antibiotics for lactating dairy cattle. Another animal health company based in the United States advocates a fresh cow protocol with identification and treatment of quarter infections at freshening.

In this study, cows were not specifically treated based upon testing at $\mathrm{d} 3$. Our results indicated that $\mathrm{d} 3$ milk culture results of no growth versus any growth, as well as CMT and SCC results in 2 categories at the cut-offs evaluated, were not associated with statistically significant differences in milk production. Significant differences in 150-d milks were found when no growth of major pathogens was compared with any growth of major pathogens. However, differential cell counts at the cut-offs evaluated were often significantly associated with 150-d milk production. Additionally, occurrence of a health event in 2 or 3 categories was significantly associated $(P=0.003$ for both) with $150-\mathrm{d}$ milk production. In the case of SCC at the highest cutoff of $400,000 / \mathrm{mL}$, we did find a significant difference in milk production for animals above and below the cutoff. We did not measure total pooled SCC per cow. We speculate that total SCC would correlate with numbers of quarters above a given SCC threshold.

Few published studies guide management of udder health issues in fresh cows. Utilization of fresh cow monitoring information will vary considerably among farms and veterinarians. One study (Wallace et al., 2004) investigated a treatment protocol for IMI in early lactation based on a positive CMT test. Quarter CMT and quarter milk sampling for microbiological culture were performed by the dairy producers on 561 cows in 24 commercial herds within the first $3 \mathrm{~d}$ of calving (Wallace et al., 2004). Cows with a positive CMT (any reaction) were randomly assigned to a treatment or control group. Treatment group cows were administered intramammary cephapirin sodium, whereas control cows received no treatment. All CMT-positive cows were again sampled at 10 to 16 DIM to determine cure. Cure rates for 138 treated and 117 control quarters were not significantly different, at 85 and $72 \%$, respectively. Treatment was not associated with a significant difference in milk production. The study concluded that blanket therapy of positive cows based upon CMT results may not be justified (Wallace et al., 2004). In our study, we analyzed associations of several variables with health events. The CMT used in a manner analogous to that used by Wallace et al. (2004) was not significantly associated with health events, but milk culture, SCC, and differential cell count measures were associated with health events.

Our results suggest that testing fresh cow milks on d 3 may provide information on subsequent production. The CMT, SCC in 2 categories, and milk culture were not significantly associated with milk production, but some measures of differential cell counts were. Both percentage neutrophils and the absolute number of neutrophils in a milk sample were demonstrated to be associated with milk production, and showed advantages compared with using results of CMT testing. The CMT was found to be of questionable value in predicting milk production. The study also demonstrated an expected increasing effect on milk production as the number of quarters affected per cow increased. We suggest that measures of differential cell counting could provide additional useful information to the producer on d 3. Field trials of these tests to predict future milk production are indicated.

\section{ACKNOWLEDGMENTS}

The authors acknowledge Andy Meier and his staff at Cherry Dairy (Goldsboro, NC) for their assistance in conducting the study. John Clay and Kas Ingawa at Dairy Records Management Systems (Raleigh, NC) contributed to production data analysis. We gratefully acknowledge the support of the Merck-Merial Veterinary Scholars Program at the College of Veterinary Medicine at North Carolina State University (Raleigh) and Advanced Animal Diagnostics Inc. (AAD Inc., Durham, NC). We thank Debbie Asion of AAD Inc. and Roberta Lyman of the North Carolina State College of Veterinary Medicine for laboratory work.

\section{REFERENCES}

Aalseth, E. 2005. Fresh cow management: What is important, what does it cost and what does it return. Pages 1-12 in Proc. 7th Western Dairy Management Conf., Reno, NV. Kansas State University and Cooperative Extension Service, Manhattan.

Anderson, K. L., R. R. Rodriguez, D. Asion, J. Wilder, and A. Krebbs. 2006. An easy technique for milk somatic cell differential counts. Pages 185-196 in Proc. III Panamerican Congress on Mastitis Control and Milk Quality, Leon, Guanajuato, Mexico. Acontecer Lechero, Distrito Federal, Mexico.

Barkema, H. W., H. A. Deluyker, Y. H. Schukken, and T. J. G. M. Lam. 1999. Quarter-milk somatic cell count at calving and at the first six milkings after calving. Prev. Vet. Med. 38:1-9.

Britten, A. 2004. Implementing and evaluating fresh cow mastitis programs. Pages 78-82 in Proc. Natl. Mastitis Counc. 43rd Ann. Mtg., Charlotte, NC. National Mastitis Council, Verona, WI.

De Vliegher, S., H. W. Barkema, H. Stryhn, G. Opsomer, and A. de Kruif. 2004. Impact of early lactation somatic cell count in heifers on somatic cells over the first lactation. J. Dairy Sci. 87:36723682 .

DHIA. 2007. DHI Glossary Fact Sheet, May, 2007. Dairy Records Management Systems, Raleigh, NC. http://www.drms.org/ Accessed Nov. 7, 2007. 
Dingwell, R., K. Leslie, L. Timms, Y. Schukken, and J. Sargeant. 2004. Evaluation of the California Mastitis Test to determine udder health status of early lactation dairy cows. A.S. Leaflet R1913. Iowa State University Animal Industry Report 2004, Dairy. http:// www.ans.iastate.edu/report/air/2004pdf/AS1913.pdf. Accessed Oct. 29, 2008.

Dingwell, R. T., K. E. Leslie, Y. H. Schukken, J. M. Sargeant, and L. L. Timms. 2003. Evaluation of the California mastitis test to detect an intramammary infection with a major pathogen in early lactation dairy cows. Can. Vet. J. 44:413-415.

Harmon, R. J. 1994. Physiology of mastitis and factors affecting somatic cell counts. J. Dairy Sci. 77:2103-2112.

Hogan, J. S., R. N. González, R. J. Harmon, S. C. Nickerson, S. P. Oliver, J. W. Pankey, and K. L. Smith. 2005. Laboratory Handbook on Bovine Mastitis. Rev. ed. National Mastitis Council, Verona, WI.

Pfizer Animal Health. 2009. Fresh cow programs, FRESH START ${ }^{\text {SM }}$ protocol. http://www.100daycontract.com. Accessed Feb. 10, 2009.

Pillai, S. R., E. Kunze, L. M. Sordillo, and B. M. Jayarao. 2001. Application of differential inflammatory cell count as a tool to monitor udder health. J. Dairy Sci. 84:1413-1420.

Quaife, T. 2005. Four ways to monitor fresh-cow health. Dairy Herd Management, 11/1/2005. http://www.dairyherd.com/ Accessed July $7,2007$.
Rampino, M. L., M. T. Correa, A. Meier, and K. L. Anderson. 2006. Analysis of milk somatic cell counts (SCC) of dairy heifers in early lactation from Cherry dairy farm. Pages 69-74 in Proc. 6th MidAtlantic Dairy Grazing Conference, Goldsboro, NC. Department of Animal Science, North Carolina State University, Raleigh.

Rivas, A. L., F. W. Quimby, J. Blue, and O. Coksaygan. 2001. Longitudinal evaluation of bovine mammary gland health status by somatic cell counting, flow cytometry, and cytology. J. Vet. Diagn. Invest. 13:399-407.

Sargeant, J. M., K. E. Leslie, J. E. Shirley, B. J. Pulkrabek, and G. H. Lim. 2001. Sensitivity and specificity of somatic cell count and California Mastitis Test for identifying intramammary infection in early lactation. J. Dairy Sci. 84:2018-2024.

SAS Institute. 2002-2003. SAS User's Guide: Statistics. Version 9.1 for Windows. SAS Institute Inc., Cary, NC.

Schukken, Y. H., D. J. Wilson, F. Welcome, L. Garrison-Tikofsky, and R. N. Gonzalez. 2003. Monitoring udder health and milk quality using somatic cell counts. Vet. Res. 34:579-596.

Wallace, J. A., K. Stipetic, Y. H. Schukken, R. T. Dingwell, P. Baillargeon, G. Bacic, and K. E. Leslie. 2004. An evaluation of a treatment protocol for intramammary infections in early postpartum dairy cows based on a positive California Mastitis Test result. Bovine Pract. $38: 72-78$ 